\title{
Chino del tomate virus: Relationships to Other Begomoviruses and Identification of A-Component Variants that Affect Symptom Expression
}

\author{
J. K. Brown, Kristin M. Ostrow, Ali M. Idris, and Drake C. Stenger
}

First and third authors: Department of Plant Sciences, University of Arizona, Tucson 85721; and second and fourth authors: Department of Biological Sciences, Northern Illinois University, DeKalb 60115.

Current address of K. M. Ostrow: McArdle Laboratory for Cancer Research, University of Wisconsin Medical School, Madison 53706.

Current address of D. C. Stenger: USDA-ARS and Department of Plant Pathology, University of Nebraska, Lincoln 68583.

Accepted for publication 19 January 2000.

\begin{abstract}
Brown, J. K., Ostrow, K. M., Idris, A. M., and Stenger, D. C. 2000. Chino del tomate virus: Relationships to other begomoviruses and identification of A-component variants that affect symptom expression. Phytopathology 90:546-552.

Phylogenetic and distance analyses place Chino del tomate virus (CdTV) in the New World clade of begomoviruses and indicate that CdTV and Tomato leaf crumple virus (TLCrV) are closely related strains of the same virus. One cloned CdTV A component (pCdTV-H6), when inoculated to tomato with the B component (pCdTV-B52), produced mild symptoms and low DNA titers. Another cloned CdTV A component (pCdTV-H8), when coinoculated to tomato with the B component, produced moderate leaf curling and veinal chlorosis similar to that of TLCrV. Coinoculation of both CdTV A components and the B component to tomato produced wild-type chino del tomate (CdT) disease symptoms consisting of severe leaf curling, veinal and interveinal chlorosis, and stunting. The two CdTV A components were nearly identical, except at nucleotide positions 1,722

and 2,324. The polymorphism at nucleotide 1,722 resulted in a change at Rep amino acid 261. The second polymorphism at nucleotide 2,324 resulted in changes at Rep amino acid 60 and AC4 amino acid 10. Two chimeric A components constructed by reciprocal exchange of a fragment bearing the polymorphic site at nucleotide 1,722 were evaluated for symptom phenotype. One chimeric A component (pCdTV-H86) produced wild-type CdT symptoms when coinoculated to tomato with the B component. The reciprocal chimeric A component (pCdTV-H68), when coinoculated to tomato with the B component, also produced severe leaf curling, veinal chlorosis, and stunting. However, pCdTV-H68 induced less obvious interveinal chlorosis than wild-type or pCdTV-H86. Examination of A component genotypes recovered from tomato coinoculated with pCdTV-H6 and pCdTV-H8 indicated that recombination occurred to produce a genotype identical to pCdTV-H86. These results indicate that subtle genotypic variation has significant effects on symptom expression and may explain phenotypic differences observed among isolates and cloned DNAs of CdTV and TLCrV.
\end{abstract}

Geminiviruses transmitted by whiteflies belong to the genus Begomovirus, formerly genus Subgroup III (32). Begomoviruses of the New World have bipartite genomes consisting of two circular, single-stranded DNA molecules of $\approx 2.6 \mathrm{~kb}(3,30)$. The A and $\mathrm{B}$ genome components of bipartite begomoviruses share a common region (CR) sequence of 160 to 230 nucleotides that contains cis-acting elements of the origin (ori) of DNA replication (20,31). The A component of bipartite begomoviruses encodes all viral proteins required for virus replication (37) and encapsidation (43). The B component of bipartite begomoviruses encodes two proteins that act cooperatively to move viral DNA from cell to cell $(34,39)$. Some begomoviruses of the Old World also are bipartite (for example, African cassava mosaic virus [ACMV]; 41), whereas others have monopartite genomes (for example, Tomato yellow leaf curl virus-Israel [TYLCV-IS]; 33) similar to the A component of bipartite begomoviruses. Phylogenetic studies indicate that begomoviruses of the New and Old Worlds cluster in separate clades

Corresponding author: J. K. Brown; E-mail address: jbrown@ag.arizona.edu

Mention of proprietary or brand names are necessary to report factually on available data; however, the USDA neither guarantees nor warrants the standard of the product, and the use of the name by the USDA implies no approval to the exclusion of others that also may be suitable.

Publication no. P-2000-0329-01R

This article is in the public domain and not copyrightable. It may be freely reprinted with customary crediting of the source. The American Phytopathological Society, 2000.
$(18,35,38)$, suggesting an ancient divergence of begomoviruses originating in the two hemispheres.

Numerous whitefly-transmitted begomoviruses have emerged during the last 30 years as serious pathogens of cultivated crops throughout tropical and subtropical regions of the world. Intensification of agricultural practices, increases in populations of the whitefly vector, Bemisia tabaci (Genn.), and the displacement in the New World of the A biotype of B. tabaci with the more aggressive and polyphagous B biotype have facilitated the emergence of begomoviruses into crop species (4). In the New World, emerging begomoviruses have been most damaging in legumes $(2,10$, $18,23,24)$, tomato $(1,7,27,36)$, pepper $(8,11,22,42)$, and cucurbits $(13,15,19)$. Begomoviruses are common throughout the Caribbean Basin, Mexico, and Central and South America. Begomovirus epidemics occur as far north as Florida, Texas, and in the Sonoran Desert agroecosystem of southern California, Arizona, and Sonora.

Chino del tomate (CdT) disease was first noticed on cultivated tomatoes grown in the coastal production areas of Sinaloa in Sonora State, Mexico, during 1970 and 1971 (21). Epidemics of CdT disease occurred during the 1970s and 1980s and were associated with high populations of the whitefly vector $(6,21)$. Partial characterization of geminate virus particles recovered from CdT diseased tomatoes $(5,6)$ suggested that a geminivirus, designated Chino del tomate virus (CdTV) may be the causal agent of CdT disease. Virus-vector relationships (7) were consistent with a geminivirus as the causal agent of CdT disease. Partial nucleotide sequences available for CdTV and Tomato leaf crumple virus (TLCrV), a virus later isolated from tomato in Sinaloa, Mexico (36), suggested that the two viruses are closely related and may constitute strains 
of a single virus species (45). Recently, the complete nucleotide sequences of CdTV (9) and TLCrV (28) have been reported, permitting the direct and complete comparison of sequences presented here. The occurrence of other geminiviruses infecting tomatoes in the Sonoran Desert led others (40) to speculate that a mixture of Pepper hausteco virus (PHV) and the A component of Texas pepper virus (TPV) might cause CdT disease. However, in this article we demonstrate that CdTV does cause CdT disease. We further demonstrate that minor nucleotide substitutions occurring in two CdTV A components significantly affect symptom expression; cloned CdTV A components that differ in sequence by only one or two nucleotides can result in distinct symptoms.

\section{MATERIALS AND METHODS}

CdTV virus isolate and maintenance. The CdTV isolate used in this study was originally collected in 1983 in Sinaloa, Mexico, from tomato exhibiting CdT disease symptoms and is the prototype isolate used for the initial characterization of CdTV (7). This CdTV culture was maintained in greenhouse-grown tomato by serial transmission, using either the whitefly vector as described (7), or by biolistic inoculation (12) of tomato seedlings with DNA extracted from CdTV-infected plants.

Cloning and sequencing of the CdTV genome. CdTV DNA was identified and cloned by methods used for Bean calico mosaic virus (BCMoV) (10). Total DNA was extracted from tomato infected with CdTV, and aliquots were incubated with various restriction endonuclease enzymes. Restriction endonuclease products derived from CdTV replicative form (RF) DNA were detected by Southern hybridization using virion-sense riboprobes transcribed from pTPV-MA1 (A component) and pTPV-MB1 (B component). pTPV-MA1 and pTPV-MB1 (D. C. Stenger, unpublished data) contain full-length inserts of a mosaic-inducing strain of the begomovirus provisionally designated (42) as TPV-M. Apparent full-length linear products of the CdTV A (HindIII-digested) and B (BamHI-digested) components were identified and isolated from agarose gels. Gel-purified, linearized CdTV RF DNA was ligated to pGEM7Zf+ (Promega Corp., Madison, WI), previously linearized with the appropriate restriction endonuclease and the ligation products transformed into Escherichia coli DH5 $\alpha$ cells. Clones containing recombinant plasmids bearing CdTV DNA inserts were identified by colony hybridization with riboprobes transcribed from pTPV-MA1 and pTPV-MB1. Recombinant plasmids bearing full-length inserts of the CdTV A (pCdTV-H6 and pCdTV$\mathrm{H} 8$ ) or B (pCdTV-B52) components were identified and used in subsequent analyses.

Sequencing templates bearing nested deletions in both orientations were generated for each cloned CdTV DNA insert, using the Erase-A-Base kit (Promega). Templates generated by the Erase-ABase procedure were sequenced by the Iowa State University (Ames) DNA Sequencing Facility. Sequences were compiled using the Sequencher 3.1 program (Gene Codes, Ann Arbor, MI). GenBank Accession numbers for the CdTV A component sequences are AF226665 (pCdTV-H6) and AF226664 (pCdTV-H8). The GenBank Accession number for the CdTV B component is AF226666 (pCdTVB52). Open reading frames (ORFs) were identified using the DNA Inspector IIe program (Textco, West Lebanon, NH).

Phylogenetic analysis of the CdTV genome. Geminiviruses used in comparative sequence analyses for and their respective acronyms and GenBank Accession numbers are shown in Table 1. The AV1 ORF (encoding the coat protein) of Sinaloa tomato leaf curl virus (STLCV) (GenBank Accession no. AF040635) was used for comparison with CdTV, because full-length sequences for STLCV are not available.

Sequence comparisons were based on distance and maximum parsimony methods using the PAUP 3.1.1 program (44). For each analysis, a most parsimonious tree was sought using a heuristic search with stepwise addition and the tree bisec- tion-reconnection branch-swapping options in effect. Bootstrap values were based on 200 replicates using the $>60 \%$ majority rule option.

Construction of chimeric CdTV A components. Determination of the nucleotide sequences of pCdTV-H6 and pCdTV-H8 revealed that the two A components differed in nucleotide sequence at only two positions (Fig. 1). The polymorphic nucleotide at position 1,722 was either a T (pCdTV-H8) or a C (pCdTV-H6). The polymorphic nucleotide at position 2,324 was either an $\mathrm{A}$ (pCdTV-H8) or a G (pCdTV-H6). Chimeric CdTV A components were constructed by the reciprocal exchange between pCdTV-H6 and pCdTV-H8 of a 739-bp SalI-BstZI fragment (nucleotides 1,128 to 1,866 ) that contained the polymorphic nucleotide at position 1,722. The resulting plasmids containing chimeric CdTV A component inserts were pCdTV-H68 ( $\mathrm{T}$ and $\mathrm{G}$ at positions 1,772 and 2,324 , respectively) and pCdTV-H86 (C and A at positions 1,722 and 2,324, respectively).

Infectivity assays with cloned CdTV DNA. CdTV DNA inserts were excised from recombinant plasmids by digestion with the same restriction endonuclease enzyme used to clone each insert. Excised CdTV DNA inserts were delivered to test plants by biolistic inoculation (12) as a mixture containing $0.5 \mu \mathrm{g}$ of each excised CdTV insert. Inoculated plants were maintained in an insect-free greenhouse and monitored for symptom development. The presence or absence of CdTV DNA in inoculated plants was determined by polymerase chain reaction (PCR) of the AV1 ORF as described previously (46). Accumulation of viral DNA forms in infected plants was determined by Southern hybridization of total DNA extracts with component-specific probes (A component nucleotides 115-1,256; B component nucleotides 917-1,823). To evaluate A-component genotypes present in tomato inoculated with a mixture of pCdTV-H6 and pCdTV-H8, an 860-bp PCR product (CdTV A component nucleotides 1,601-2,460) containing both polymorphic sites was amplified from total DNA extracts of systemically infected tissue, cloned into pGEM-T (Promega), and sequenced. Primers used to amplify the PCR product were $5^{\prime}$-TTTCTCACATATCCCCAGTGCTCTCTTAGC-3' (complementary sense) and 5'-GGGATACCTCCTTTAATTTGAACTGGCTTG-3' (virion sense).

TABLE 1. Geminiviruses used in comparative sequence analyses ${ }^{\mathrm{a}}$

\begin{tabular}{|c|c|c|c|}
\hline \multirow[b]{2}{*}{ Name } & \multirow[b]{2}{*}{ Acronym } & \multicolumn{2}{|c|}{ Accession number } \\
\hline & & A component & B component \\
\hline Abutilon mosaic virus-Hawaii & AbMV-HI & U51137 & U51138 \\
\hline Abutilon mosaic virus-West Indies & AbMV-WI & X15983 & X15984 \\
\hline African cassava mosaic virus-Kenya & ACMV-KE & J02057 & J02058 \\
\hline Bean calico mosaic virus & $\mathrm{BCMoV}$ & AF110189 & AF110190 \\
\hline Bean dwarf mosaic virus & BDMV & M88179 & M88180 \\
\hline Bean golden mosaic virus-Brazil & BGMV-BR & M88686 & M88687 \\
\hline Bean golden mosaic virus-Puerto Rico & BGMV-PR & M10070 & M10080 \\
\hline Bean golden mosaic virus-Guatemala & BGMV-GA & M91604 & M91605 \\
\hline Cabbage leaf curl virus & $\mathrm{CaLCV}$ & U65529 & U65530 \\
\hline Havana tomato virus & HTV & Y14874 & Y14875 \\
\hline Indian cassava mosaic virus & ICMV & Z24758 & Z24759 \\
\hline Indian tomato leaf curl virus & IToLCV & Z48182 & NA \\
\hline Pepper hausteco virus & PHV & X70418 & X70419 \\
\hline Potato yellow mosaic virus & PYMV & D00940 & D00941 \\
\hline Sida golden mosaic virus & SiGMV & X99550 & X99551 \\
\hline Squash leaf curl virus-E & SLCV-E & M38183 & M38182 \\
\hline Taino tomato mottle virus & TTMoV & AF012300 & AF012301 \\
\hline Texas pepper virus-Tamaulipas & TPV-TAM & U57457 & NA \\
\hline Tomato golden mosaic virus & TGMV & K02029 & K02030 \\
\hline Tomato leaf crumple virus & TLCrV & AF101476 & AF101478 \\
\hline Tomato leaf curl virus-Australia & ToLCV-AU & S53251 & NB \\
\hline Tomato leaf curl virus-New Delhi & ToLCV-ND & U15015 & U15017 \\
\hline Tomato leaf curl virus-Taiwan & ToLCV-TW & U88692 & NB \\
\hline Tomato mottle virus & ToMoV & L14460 & L14461 \\
\hline Tomato yellow leaf curl virus-Israel & TYLCV-IS & $\mathrm{X} 15656$ & NB \\
\hline Tomato yellow leaf curl virus-Sardinia & TYLCV-SAR & X61153 & NB \\
\hline Tomato yellow leaf curl virus-Spain & TYLCV-SP & Z25751 & NB \\
\hline
\end{tabular}

a NA indicates sequence not available; NB indicates virus has no B component. 


\section{RESULTS}

CdTV genome organization and variability. Analysis of the nucleotide sequences of cloned genome components indicated that CdTV is a typical bipartite begomovirus encoding five ORFs on the A component and two ORFs on the B component (Fig. 1). The two CdTV A-component clones (pCdTV-H8 and pCdTV-H6) yielded nearly identical nucleotide sequences that varied at only two positions (Fig. 1). The polymorphisms at nucleotide positions 1,722 and 2,324 each resulted in amino acid substitutions when the affected ORFs were conceptually translated. The substitution at position 1,722 results in a polymorphism at amino acid residue 261 of the Rep protein encoded by the AC1 ORF. In pCdTV-H8, Rep amino acid 261 is an isoleucine residue, whereas in pCdTV-H6 Rep amino acid 261 is a valine residue. This polymorphic residue at Rep amino acid 261 is within a region of the Rep protein that has been hypothesized to serve as a helicase $(25,26)$, although this activity has not been experimentally demonstrated. Rep amino acid 261 is located $\approx 30$ amino acid residues downstream of a con-
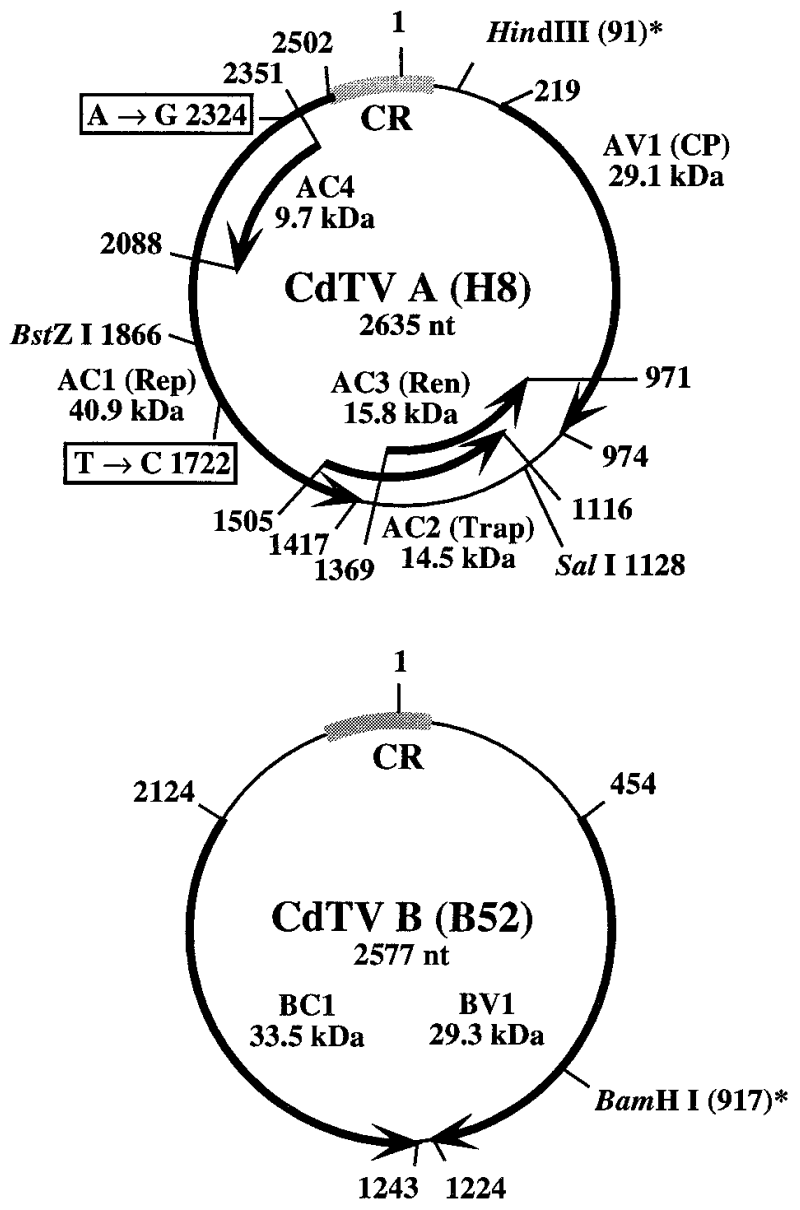

Fig. 1. Genome organization of Chino del tomate virus (CdTV). Physical maps of CdTV A and B components based on complete nucleotide sequences for infectious clones pCdTV-H8 (DNA A) and pCdTV-B52 (DNA B). Arrows indicate the location and polarity of open reading frames (ORFs) present on the CdTV genome that are conserved among begomoviruses. Nucleotide 1 of each genome component is indicated and defined as the first nucleotide $3^{\prime}$ of the Rep protein nick site within the ori. Shaded arc indicates common region (CR) sequences conserved among the two CdTV DNA components. Sizes of predicted proteins are given in kilodaltons. Nucleotide coordinates of ORF start and stop codons are indicated. Positions of nucleotide substitutions among the two cloned A components of CdTV are indicated within boxes ( $\mathrm{H} 8$ base $\rightarrow \mathrm{H} 6$ base). The locations of endonuclease restriction sites used to clone each genome component are indicated by an asterisk; other endonuclease restriction sites identified on the A component define the fragments exchanged among pCdTV-H6 and pCdTV-H8 used to construct chimeric CdTV A components. served NTP-binding motif (required in a helicase) that, when mutated, reduces or abolishes ATPase activity of Rep as well as viral DNA replication (14). The carboxy-terminal third of the Rep protein is highly variable among begomoviruses, with the exception of the aforementioned NTP-binding motif and the amino acid residues including and surrounding amino acid 261. Within this region, most begomoviruses have the motif YNVIDD that matches the predicted Rep amino acid sequence in pCdTV-H8. The same motif in pCdTV-H6 would be translated as YNVDDD. Although this represents a conservative amino acid substitution (I to V), the sequence of this motif in pCdTV-H6 does not match that of any other geminivirus in GenBank.

The polymorphic nucleotide at position 2,324 occurs in a region in which two ORFs in different reading frames overlap (Fig. 1). As a result, both the AC1 ORF encoding Rep and the AC4 ORF encoding a small, hypothetical protein of unknown function are altered. In pCdTV-H8, Rep amino acid 60 is a valine residue, whereas in pCdTV-H6 Rep amino acid 60 is an alanine residue. This residue is within the putative metal ion binding site conserved among replication initiator proteins of rolling circle replicons (29). In pCdTV-H8, the metal ion binding motif of the Rep protein is HLHVLIQ. In pCdTV-H6, the corresponding sequence is HLHALLIQ. Rep proteins of other sequenced geminiviruses have valine, alanine, or cysteine at Rep amino acid 60 . The polymorphism at nucleotide 2,324 also affects the tenth codon of the AC4 ORF, which is phenylalanine in pCdTV-H8 and leucine in pCdTV-H6. The AC4 ORF varies considerably among geminiviruses; therefore, a number of different amino acid residues are found at this position in divergent geminiviruses.

Relationship of CdTV to other geminiviruses. The nucleotide sequence identities of the CdTV A component (pCdTV-H8), B component (pCdTV-B52), and AV1 (coat protein) ORF relative to other begomoviruses are listed in Table 2. CdTV and TLCrV are

TABLE 2. Nucleotide identity (percent) between Chino del tomate virus and other begomoviruses $^{\mathrm{a}}$

\begin{tabular}{|c|c|c|c|}
\hline $\begin{array}{l}\text { Origin } \\
\text { Virus }\end{array}$ & $\begin{array}{c}\text { DNAA } \\
(\%)\end{array}$ & $\begin{array}{c}\text { AV1 } \\
\text { ORF }(\%)\end{array}$ & $\begin{array}{c}\text { DNA B } \\
(\%)\end{array}$ \\
\hline \multicolumn{4}{|l|}{ Old World } \\
\hline African cassava mosaic virus -Kenya & 64.3 & 65.6 & 48.0 \\
\hline Tomato leaf curl virus (ToLCV)-New Delhi & 64.4 & 66.7 & 40.3 \\
\hline Indian cassava mosaic virus & 65.3 & 67.4 & 40.9 \\
\hline ToLCV-Taiwan & 64.7 & 67.6 & NB \\
\hline ToLCV-Australia & 65.4 & 67.4 & NB \\
\hline Tomato yellow leaf curl virus (TYLCV)-Israel & 66.0 & 67.0 & NB \\
\hline TYLCV-Sardinia & 63.8 & 62.8 & NB \\
\hline TYLCV-Spain & 64.3 & 64.8 & NB \\
\hline Indian tomato leaf curl virus & 64.8 & 68.1 & NA \\
\hline \multicolumn{4}{|l|}{ New World } \\
\hline Abutilon mosai & 84.4 & 87.8 & 73.3 \\
\hline AbMV-West Indies & 85.1 & 87.7 & 72.0 \\
\hline Bean calico mosaic virus & 72.5 & 81.4 & 65.2 \\
\hline Bean dwarf mosaic virus & 83.7 & 87.2 & 75.5 \\
\hline Bean golden mosaic virus (BGMV)-Brazil & 76.1 & 81.7 & 64.4 \\
\hline BGMV-Puerto Rico & 75.8 & 79.7 & 65.4 \\
\hline BGMV-Guatemala & 76.1 & 81.6 & 65.3 \\
\hline Cabbage leaf curl virus & 72.2 & 82.4 & 66.0 \\
\hline Havana tomato virus & 82.9 & 86.2 & 70.2 \\
\hline Pepper hausteco virus & 70.3 & 77.9 & 64.3 \\
\hline Potato yellow mosaic virus & 81.2 & 85.3 & 67.7 \\
\hline Sida golden mosaic & 83.2 & 84.9 & 78.4 \\
\hline Squash leaf curl virus $-\mathrm{E}$ & 70.7 & 80.5 & 64.0 \\
\hline Sinaloa tomato leaf curl virus & NA & 84.8 & NA \\
\hline Tomato golden mosaic virus & 75.9 & 81.0 & 64.6 \\
\hline Tomato leaf crumple virus & 97.4 & 98.1 & 93.0 \\
\hline Tomato mottle virus & 84.7 & 87.4 & 71.7 \\
\hline rus-Tamaulipas & 69.3 & 80.7 & NA \\
\hline Taino tomato mottle virus & 84.7 & 84.7 & 72.2 \\
\hline
\end{tabular}

a $\mathrm{ORF}=$ open reading frame; $\mathrm{NA}=$ sequence not available; $\mathrm{NB}=$ virus has no B component. 
clearly sister taxa, with percent identities of DNA A (97.4\%), AV1 (98.1\%), and DNA B (93.0\%) all well above the $90 \%$ identity threshold established (32) for defining two begomovirus taxa as strains of the same virus. No other known begomovirus shares $>90 \%$ nucleotide sequence identity with CdTV (Table 2).

The CdTV A and B component CR sequences were nearly identical (99.4\% nucleotide identity), whereas the TLCrV A and B component CR sequences were divergent (87.8\% nucleotide identity) from one another (Fig. 2). The A component CR of CdTV and TLCrV also were very similar, sharing 99.4\% nucleotide sequence identity, whereas the CdTV and TLCrV B component CRs were less conserved ( $88.3 \%$ nucleotide sequence identity). Nonetheless, all CR motifs known to confer ori function and replication specificity were identical between CdTV and TLCrV (Fig. 2).

Phylogenetic analysis based on maximum parsimony (Fig. 3) indicates that both components of CdTV group within the Abutilon mosaic virus cluster of New World begomoviruses. Both A and $\mathrm{B}$ component phylogenetic analyses confirm that CdTV and TLCrV share a most recent common ancestor among the begomovirus taxa examined. A similar result was obtained when phylogenetic analysis of the AV1 ORF was performed (data not shown).

Infectivity and symptom phenotypes of cloned CdTV components. Systemic infection of tomato was achieved with either pCdTV-H8 or pCdTV-H6 as the A component coinoculated with the B component clone pCdTV-B52 (Table 3). However, the two CdTV A components induced different symptoms. The combination of pCdTV-H6 and pCdTV-B52 produced only mild leaf curling and veinal chlorosis. In contrast, the combination of pCdTVH8 and pCdTV-B52 produced more obvious leaf curling and discontinuous veinal chlorosis, resembling symptoms reported for clones of TLCrV recovered after passage in bean (36) but not those of wild-type CdTV. Neither cloned CdTV A component alone, when coinoculated with pCdTV-B52, induced the severe disease symptoms associated with the wild-type CdTV culture; therefore, inoculation of tomato with both cloned A components and the B component was attempted. Infection of tomato plants inoculated with a combination of pCdTV-H8, pCdTV-H6, and pCdTV-B52 resulted in severe systemic leaf curling, veinal and interveinal chlorosis, and stunting symptoms very similar to those of the original CdTV culture (Table 3). Coinoculation of the chimeric A components pCdTV-H68 or pCdTV-H86 with pCdTV-B52 each resulted in severe disease symptoms. pCdTV-H86 and pCdTV-B52 induced

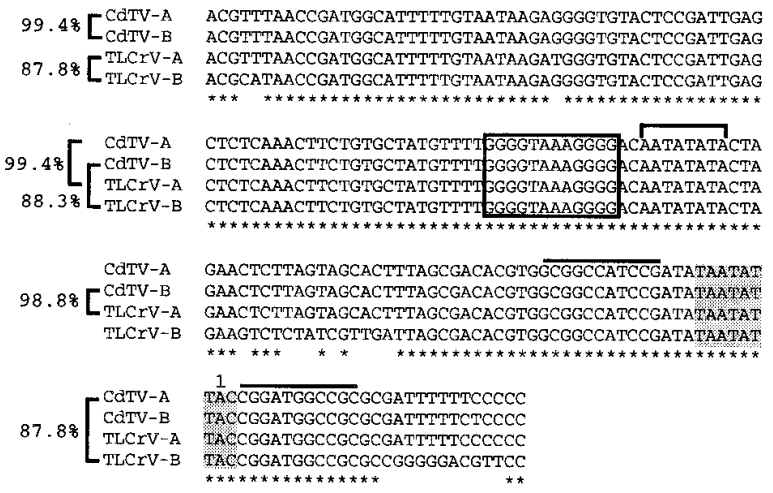

Fig. 2. Alignment of Chino del tomate virus (CdTV) common region (CR) sequences with those of Tomato leaf crumple virus (TLCrV). Percent values to the left indicate the overall nucleotide identity of CR sequences in each possible two-way comparison. Asterisks indicate the positions of nucleotides conserved among all sequences presented. Shaded box indicates the location of the nine-base invariant sequence containing the Rep protein nick site. The A residue immediately $3^{\prime}$ of the Rep protein nick site is designated as nucleotide 1. Lines indicate limits of inverted repeats flanking the invariant sequence that collectively form the stem-loop structure of the ori. Open rectangle indicates the limits of the Rep protein binding site serving as the primary determinant of replication specificity. Location of the AC1 open reading frame TATA box is bracketed.
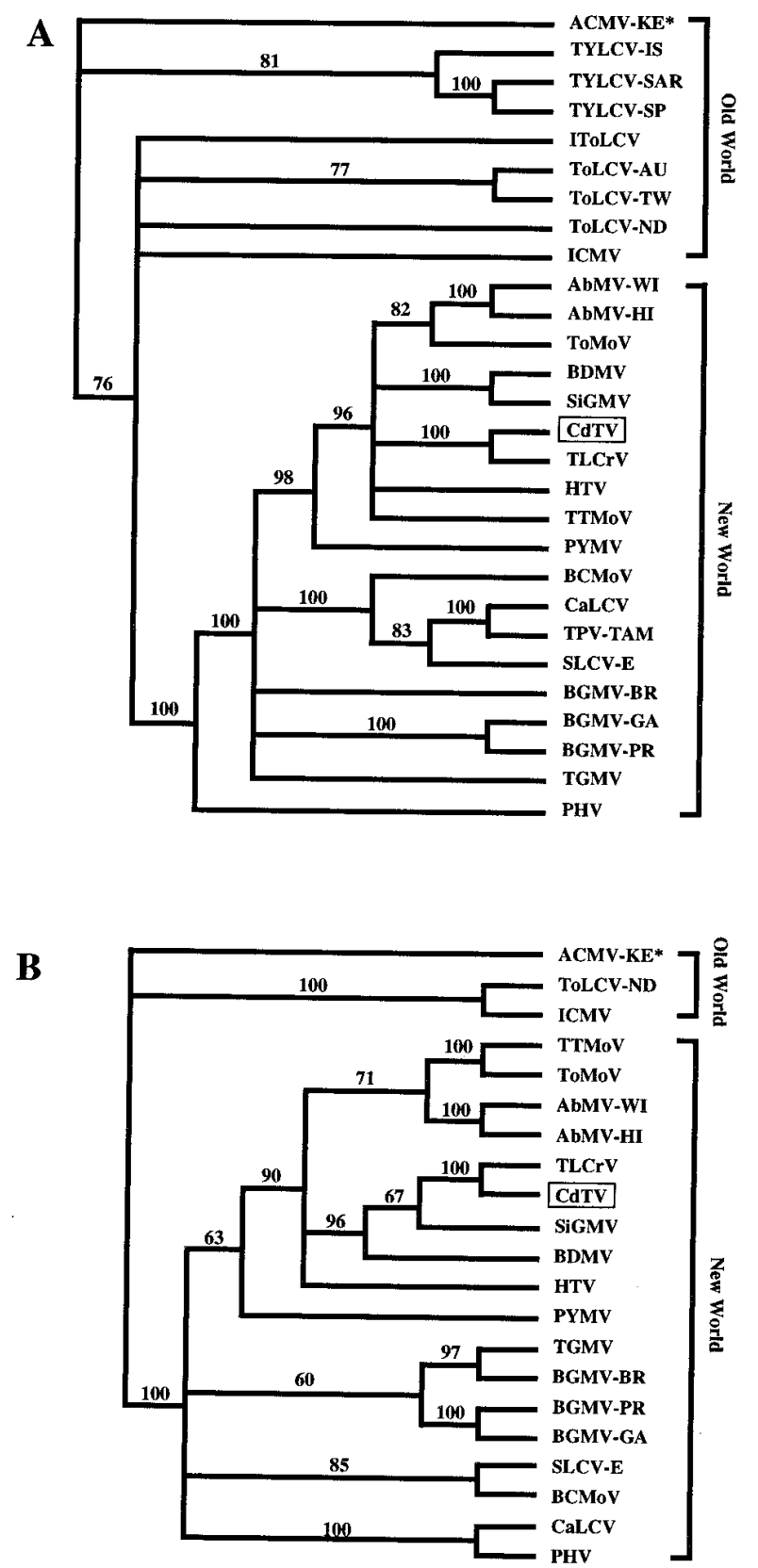

Fig. 3. Phylogenetic relationship of Chino del tomate virus (CdTV) to other begomoviruses. Presented are $60 \%$ majority-rule consensus trees of the A, A component-monopartite genomes and B, B component nucleotide sequences based on maximum parsimony (200 bootstrap replicates). Both vertical and horizontal branch lengths are arbitrary; only tree topology is relevant. Numbers along branches indicate bootstrap percent values assigned to each node when $>60 \%$. Asterisks denote African cassava mosaic virusKenya (ACMV-KE) used as an outgroup to root each tree. Placement of CdTV in each tree is highlighted with a rectangle. The geographic origin (New or Old World) of begomovirus taxa are indicated to the right with brackets. Other viruses: Abutilon mosaic virus-Hawaii (AbMV-HI), AbMVWest Indies (AbMV-WI), Bean calico mosaic virus (BCMoV), Bean dwarf mosaic virus (BDMV), Bean golden mosaic virus-Brazil (BGMV-BR), BGMV-Puerto Rico (BGMV-PR), BGMV-Guatemala (BGMV-GA), Cabbage leaf curl virus (CaLCV), Havana tomato virus (HTV), Indian cassava mosaic virus (ICMV), Indian tomato leaf curl virus (IToLCV), Pepper hausteco virus (PHV), Potato yellow mosaic virus (PYMV), Sida golden mosaic virus (SiGMV), Squash leaf curl virus-E (SLCV-E), Taino tomato mottle virus (TTMoV), Texas pepper virus-Tamaulipas (TPV-TAM), Tomato golden mosaic virus (TGMV), Tomato leaf crumple virus (TLCrV), Tomato leaf curl virus-Australia (ToLCV-AU), ToLCV-New Delhi (ToLCV-ND), ToLCVTaiwan (ToLCV-TW), Tomato mottle virus (ToMoV), Tomato yellow leaf curl virus-Israel (TYLCV-IS), TYLCV-Sardinia (TYLCV-SAR), and TYLCVSpain (TYLCV-SP). 
severe leaf curling, veinal and interveinal chlorosis, and stunting symptoms very similar to those of the wild-type CdTV culture or the mixture of pCdTV-H6, pCdTV-H8, and pCdTV-B52. pCdTVH68 and pCdTV-B52 also produced severe leaf curling, veinal chlorosis, and stunting but less obvious interveinal chlorosis than wild-type CdTV or pCdTV-H86.

Southern hybridization of total DNA extracts (Fig. 4) revealed that the two CdTV A components differed in the amount of viral DNA accumulated in systemically infected plants. For plants inoculated with pCdTV-H6 and pCdTV-B52, a 5- $\mu$ g sample of total DNA was necessary to yield hybridization signals similar to those obtained with $1 \mu \mathrm{g}$ of total DNA samples extracted from plants inoculated with the B component and all other combinations of one or two A components. Although the accumulation of viral DNA was reduced in plants inoculated with pCdTV-H6 as the only A component, all inocula tested produced both single- and doublestranded DNA forms typically associated with begomovirus infection (Fig. 4).

Sequence analysis of eight clones derived from the 860-bp PCR product of the A component amplified from a plant inoculated with a mixture of pCdTV-H6 and pCdTV-H8 revealed that the mixture of the two genotypes was not stable (Table 4). Five clones yielded sequence identical to pCdTV-H6. No clones bearing the pCdTV-H8 genotype were recovered. Instead, the other three clones examined represent a recombinant genotype (identical to pCdTV-H86) in which the polymorphic nucleotide at position 1,722 is a $\mathrm{C}$, as in pCdTV-H8, whereas nucleotide 2,324 is an A, as in pCdTV-H6.

TABLE 3. Infectivity and symptom expression of wild-type Chino del tomate virus (CdTV) and cloned CdTV A and B components on tomato ${ }^{\mathrm{a}}$

\begin{tabular}{|c|c|c|c|c|}
\hline \multirow[b]{2}{*}{ Inoculum (pCdTV-) } & \multicolumn{3}{|c|}{ Experiment } & \multirow[b]{2}{*}{ Symptoms $^{\mathrm{b}}$} \\
\hline & 1 & 2 & 3 & \\
\hline$-\mathrm{H} 8+-\mathrm{B} 52$ & $4 / 4$ & $3 / 4$ & $3 / 4$ & $\mathrm{LC}, \mathrm{VC}, \mathrm{Mo}$ \\
\hline$-\mathrm{H} 6+-\mathrm{B} 52$ & $0 / 4$ & $1 / 4$ & $2 / 4$ & $\mathrm{LC}, \mathrm{VC}, \mathrm{M}$ \\
\hline$-\mathrm{H} 8+-\mathrm{H} 6+-\mathrm{B} 52$ & $3 / 4$ & $3 / 4$ & $4 / 4$ & LC, IVC, VC, St, S \\
\hline$-\mathrm{H} 68+-\mathrm{B} 52$ & $3 / 4$ & $4 / 4$ & $4 / 4$ & LC, IVC ${ }^{c}, V C, S t, S$ \\
\hline$-\mathrm{H} 86+-\mathrm{B} 52$ & $4 / 4$ & $3 / 4$ & $4 / 4$ & LC, IVC, VC, St, S \\
\hline$-\mathrm{H} 68+-\mathrm{H} 86+-\mathrm{B} 52$ & $3 / 4$ & $3 / 4$ & $3 / 4$ & LC, IVC, VC, St, S \\
\hline Wild-type CdTV & $4 / 4$ & $4 / 4$ & $3 / 4$ & LC, IVC, VC, St, S \\
\hline No DNA control & $0 / 4$ & $0 / 4$ & $0 / 4$ & $\ldots$ \\
\hline
\end{tabular}

${ }^{\mathrm{a}}$ Infectivity $=$ number of plants infected per number of plants inoculated.

${ }^{\mathrm{b}} \mathrm{LC}=$ leaf curling, $\mathrm{VC}=$ veinal chlorosis, $\mathrm{IVC}=$ interveinal chlorosis, $\mathrm{St}=$ stunting, $\mathrm{M}=$ mild, $\mathrm{Mo}=$ moderate, and $\mathrm{S}=$ severe .

${ }^{\mathrm{c}}$ Interveinal chlorosis less obvious than wild-type.

TABLE 4. Chino del tomate virus (CdTV) A-component genotypes recovered after coinoculation of tomato with the cloned CdTV A components pCdTV-H6 and pCdTV-H8

\begin{tabular}{lccc}
\hline & \multicolumn{2}{c}{ Nucleotide position } & \\
\cline { 2 - 3 } Clone & 1,722 & 2,324 & Genotype \\
\hline p1-4 & C & G & H6 \\
p1-9 & C & A & H86 \\
p1-17 & C & G & H86 \\
p1-18 & C & G & H6 \\
p1-19 & C & A & H86 \\
p1-22 & C & G & H6 \\
p1-23 & C & A & H86 \\
p1-28 & C & G & H6 \\
pCdTV-H6 & C & G & H6 \\
pCdTV-H8 $^{\mathrm{a}}$ & T & A & H8 \\
pCdTV-H68 & T & G & H68 \\
pCdTV-H86 $^{\mathrm{a}}$ & $\mathrm{C}$ & $\mathrm{A}$ & H86 \\
\hline
\end{tabular}

${ }^{a}$ Clones of 860 -bp polymerase chain reaction product (A component nucleotides 1,601-2,460) amplified from a tomato plant inoculated with pCdTVH6 and pCdTV-H8.

${ }^{\mathrm{b}}$ Full-length cloned A components.

${ }^{\mathrm{c}}$ Chimeric A components constructed in vitro.

\section{DISCUSSION}

CdTV and TLCrV are strains of the same virus. The initial characterizations of CdTV (7) and TLCrV (36) suggested that these two viruses may be closely related. CdTV and TLCrV were isolated from diseased tomatoes in the same state of Mexico and share similar experimental host ranges. The two viruses were described as differing in symptom severity on tomato and in mechanical transmissibility. However, the symptoms of pCdTV-H8 coinoculated to tomato with pCdTV-B52 (Table 3) are very similar to that reported for TLCrV cloned after passage in bean (36).
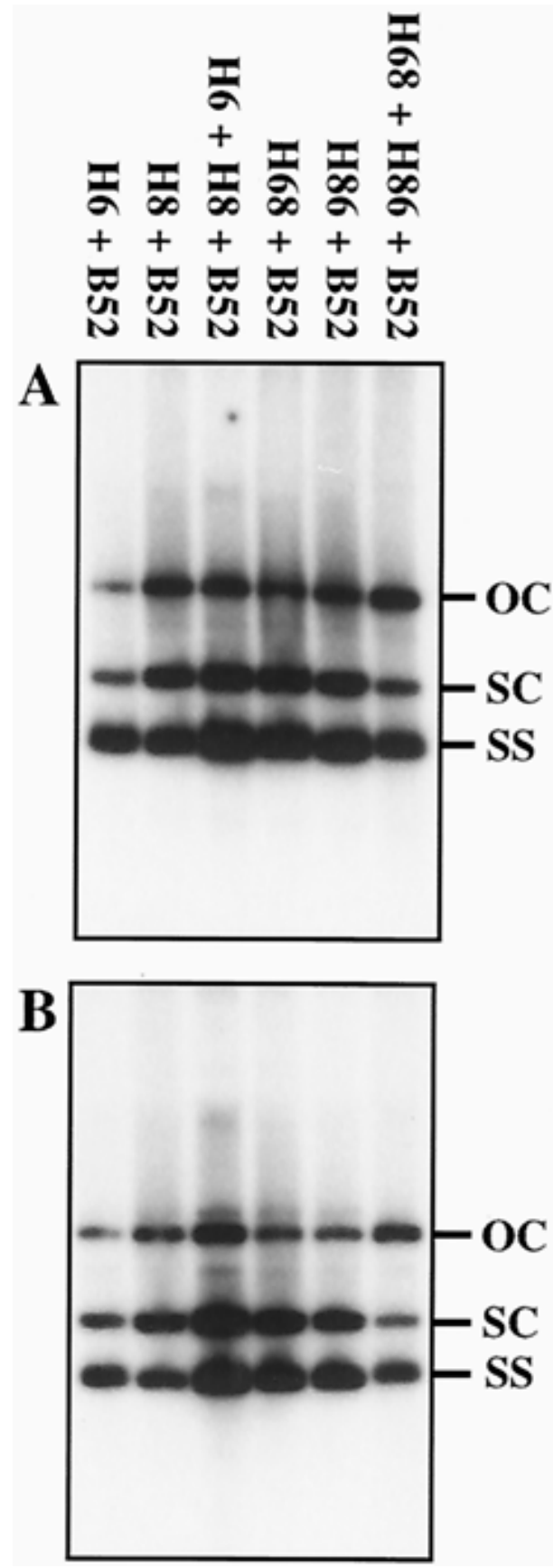

Fig. 4. Accumulation of Chino del tomate virus (CdTV) DNA forms in systemically infected tomato. Southern blots of total DNA extracts probed with A, an A or B, B component-specific probe. Cloned CdTV components used as inocula are indicated at the top. A components used as inocula were pCdTVH6 (H6), pCdTV-H8 (H8), pCdTV-H68 (H68), and pCdTV-H86 (H86). The B component used in all cases was pCdTV-B52 (B52). The mobility of singlestranded (SS), double-stranded supercoiled (SC), and open circle (OC) viral DNA forms are indicated to the right. Total DNA load was $1 \mu \mathrm{g}$ per lane for all samples, except $\mathrm{H} 6+\mathrm{B} 52$, for which $5 \mu \mathrm{g}$ per lane was used. 
This is consistent with the observation that the TLCrV A component sequence (28) has the same nucleotides as pCdTV-H8 at positions 1,722 and 2,324. Coinoculation of pCdTV-H8 and pCdTVH6 (or pCdTV-H86 alone) with pCdTV-B52 produced wild-type $\mathrm{CdT}$ disease symptoms; therefore, it is likely that the symptom differences reported for CdTV and TLCrV similarly only reflect minor differences in A-component sequence. The difference in mechanical transmissibility among CdTV and TLCrV has yet to be resolved but also may result from minor genotypic differences.

In the original description (36) of TLCrV, two distinct DNA B components were isolated after passage through Nicotiana benthamiana or bean. The two TLCrV B components were considered variants of the same virus, based on partial nucleotide sequence comparisons and similar restriction endonuclease maps but could be distinguished from one another by minor sequence variation and several unique restriction endonuclease sites (36). The two TLCrV A components recovered after passage in $N$. benthamiana and bean were identical based on restriction mapping and CR sequence (36); however, sequences at what we demonstrate to be crucial positions (A component nucleotide positions 1,722 and 2,324) were not compared.

The high nucleotide sequence identity values obtained when comparing CdTV and TLCrV sequences clearly indicate that they are sister taxa. The perfect conservation of critical cis-acting elements of the ori between CdTV and TLCrV predicts trans-replication of heterologous genome components. The discovery that minor nucleotide substitutions in the CdTV DNA A component may drastically alter symptoms demonstrates that symptom phenotype is not a reliable character for distinguishing these two taxa as different virus species. Collectively, our analysis indicates that CdTV and TLCrV represent examples of a single begomovirus species associated with the CdT disease complex.

CdTV causes CdT disease. Although neither cloned CdTV A component individually inoculated with the cloned B component produced the severe symptoms of CdT disease, coinoculation of both A components (pCdTV-H6 and pCdTV-H8) resulted in the severe symptoms characteristic of CdT disease. The production of a recombinant A-component genotype identical to pCdTV-H86, when coinoculated with pCdTV-H6 and pCdTV-H8, suggests that it is the H86 genotype that is responsible for the characteristic symptoms of CdT. This conclusion is supported by the CdT disease symptoms induced by the chimeric A component pCdTVH86 in the absence of other A component genotypes.

Since the original description of CdT disease (21), numerous geminivirus diseases of tomato have been reported in Mexico. The different symptoms described for CdTV and TLCrV have caused confusion concerning the etiology of CdT disease. Based on the genotypic and phenotypic differences observed for variants of both CdTV (this work) and TLCrV (36), it seems likely that the CdTVTLCrV species complex in the field may represent an assemblage of these and, perhaps, additional genotypes. Given the variability and plasticity of begomovirus genomes, it is reasonable to envision field populations containing additional variants such that a few polymorphic nucleotides at key positions could generate a variety of symptom phenotypes. This could explain much of the variation in disease symptoms observed in CdTV-infected tomato grown in the Sonoran Desert. The recent emergence of other begomoviruses infecting tomato in Northern Mexico $(27,40,45)$ adds further complexity to the situation. Clearly, a comprehensive field survey of the Sonoran Desert agroecosystem will be required to adequately address the population genetics of genotypic and phenotypic variation in the CdTV-TLCrV species complex.

Identification of two symptom-determinant loci. The inability of the cloned CdTV A components to produce the severe symptoms characteristic of CdT disease when individually inoculated with the $\mathrm{B}$ component indicated that each A component was defective with respect to symptom expression. The pCdTV-H6 A component produced only mild symptoms and DNA titer was reduced, whereas the pCdTV-H8 A component resulted in higher DNA titers and moderate symptoms reminiscent of TLCrV but was unable to induce wild-type CdT disease symptoms. The severe symptoms produced by either chimeric CdTV A component, or when coinoculated with (and recombination between) pCdTVH6 and pCdTV-H8, suggest that the symptom determinants mapping to nucleotides 1,722 and 2,324 interact, either directly or indirectly, with one another. Because these two polymorphic sites affect the Rep protein, it is likely that the reduced accumulation of viral DNA, observed when pCdTV-H6 was the only A component present, resulted from a partial defect in the ability of Rep to facilitate viral DNA replication. Although the hypothetical AC4 protein also could be involved, this seems unlikely, because the AC4 ORF is dispensable for infectivity, DNA replication, and symptom production in the bipartite begomoviruses Tomato golden mosaic virus (16) and ACMV (17). However, the accumulation of viral DNA to similar levels in all other treatments suggests that the symptom differences observed between pCdTV-H8 and the chimeric A components (and the in vivo recombinant resulting from coinoculation with pCdTV-H6 and pCdTV-H8) are not due to a direct effect on replicative competence. Rather, the interaction of symptom determinants observed here likely involves an as yet uncharacterized interaction among the Rep protein with itself (either inter- or intramolecular), although an interaction between Rep and AC4 cannot be formally excluded. Although the biochemical mechanism is currently unknown, the genetic evidence presented here for novel interactions is provocative, and indicates that subtle changes in viral genotype may result in complex interactions with significant effects on begomovirus pathogenesis.

\section{ACKNOWLEDGMENTS}

This research was supported in part by a grant from USDA/OICD/FAS to J. K. Brown. We thank R. French, L. Lane, and T. Petty for helpful comments.

\section{LITERATURE CITED}

1. Abouzid, A. M., Polston, J. E., and Heibert, E. 1992. The nucleotide sequence of tomato mottle virus, a new geminivirus isolated from tomatoes in Florida. J. Gen. Virol. 73:3225-3229.

2. Bird, J., Perez, J. E., Alconero, R., Vakili, N. G., and Melendez, P. L. 1972. A whitefly-transmitted golden-yellow mosaic virus of Phaseolus lunatus in Puerto Rico. J. Agric. Univ. Puerto Rico 56:64-74.

3. Bisaro, D. M. 1996. Geminivirus DNA replication. Pages 833-854 in: DNA Replication in Eukaryotic Cells. M. DePamphilis, ed. Cold Spring Harbor Laboratory Press, Cold Spring Harbor, NY.

4. Brown, J. K. 1994. Current status of Bemisia tabaci as a plant pest and virus-vector in agroecosystems worldwide. FAO Plant Prot. Bull. 42:332.

5. Brown, J. K., Goldstein, D. E., and Nelson, M. R. 1986. Partial characterization of a geminivirus isolated from tomato with yellow leaf curl symptoms. (Abstr.) Phytopathology 76:842.

6. Brown, J. K., and Hine, R. B. 1984. Geminate particles associated with the leaf curl or 'Chino' disease of tomatoes in coastal areas of Western Mexico. (Abstr.) Phytopathology 74:844.

7. Brown, J. K., and Nelson, M. R. 1988. Transmission, host range, and virus-vector relationships of chino del tomate virus, a whitefly-transmitted geminivirus from Sinaloa, Mexico. Plant Dis. 72:866-869.

8. Brown, J. K., and Nelson, M. R. 1989. Two whitefly-transmitted geminiviruses isolated from pepper affected with tigre disease. (Abstr.) Phytopathology 79:908.

9. Brown, J. K., Ostrow, K. M., Idris, A. M., and Stenger, D. C. 1998. Molecular characterization and Koch's postulates for chino del tomato geminivirus with purified virions and full-length infectious clones. (Abstr.) Phytopathology 88(suppl.):S11.

10. Brown, J. K., Ostrow, K. M., Idris, A. M., and Stenger, D. C. 1999. Biotic, molecular, and phylogenetic characterization of bean calico mosaic virus, a distinct begomovirus species with affiliation in the squash leaf curl virus cluster. Phytopathology 89:273-280.

11. Brown, J. K., and Poulos, B. T. 1990. Serrano golden mosaic virus: A newly identified whitefly-transmitted geminivirus of peppers and tomatoes in the United States and Mexico. Plant Dis. 74:720.

12. Brown, J. K., and Ryan, R. 1991. High velocity microprojectile mediated 
transmission of whitefly-transmitted geminivirus DNA or purified virions to intact plants (Abstr.) Phytopathology 81:1217.

13. Cohen, S., Duffus, J. E., Larsen, R. C., Liu, H. Y., and Flock, R. A. 1983. Purification, serology, and vector relationships of squash leaf curl virus, a whitefly-transmitted geminivirus. Phytopathology 73:1669-1673.

14. Desbiez, C., David, C., Mettouchi, A., Laufs, J., and Gronenborn, B. 1995. Rep protein of tomato yellow leaf curl geminivirus (TYLCV) has an ATPase activity required for viral DNA replication. Proc. Natl. Acad. Sci. USA 92:5640-5644.

15. Dodds, J. A., Lee, J. G., Nameth, S. T., and Laemmlen, F. F. 1984. Aphidand whitefly-transmitted cucurbit viruses in Imperial County, California. Phytopathology 74:221-225.

16. Elmer, J. S., Brand, L., Sunter, G., Gardiner, W. E., Bisaro, D. M., and Rogers, S. G. 1988. Genetic analysis of the tomato golden mosaic virus II. The product of the AL1 coding region is required for replication. Nucleic Acids Res. 16:7043-7060.

17. Etessami, P., Saunders, K., Watts, J., and Stanley, J. 1991. Mutational analysis of complementary-sense genes of Africa cassava mosaic virus DNA A. J. Gen. Virol. 72:1005-1012.

18. Faria, J. C., Gilbertson, R. L., Hanson, S. F., Morales, F. J., Ahlquist, P., Loniello, A. O., and Maxwell, D. P. 1994. Bean golden mosaic virus type II isolates from the Dominican Republic and Guatemala: Nucleotide sequences, infectious pseudorecombinants, and phylogenetic relationships. Phytopathology 84:321-329.

19. Flock, R. A., and Mayhew, D. 1981. Squash leaf curl, a new disease of cucurbits in California. Plant Dis. 65:75-76.

20. Fontes, E. P. B., Gladfelter, H. J., Schaffer, R. L., Petty, I. T. D., and HanleyBowdoin, L. 1994. Geminivirus replication origins have a modular organization. Plant Cell 6:405-416.

21. Gallegos, H. M. 1978. Enchinamiento del tomate (chino disease of tomato). Page 119 in: Enfermedades de cultivos en el estado de Sinaloa. Secretaria de Agricultura y Recursos Hidraulicos, Sinaloa, Mexico.

22. Garzon-Tiznado, J. A., Torres-Pacheco, I., Ascencio-Ibanez, J. T., HerreraEstrella, L., and Rivera-Bustamante, R. F. 1993. Inoculation of peppers with infectious clones of a new geminivirus by a biolistic procedure. Phytopathology 83:514-521.

23. Gilbertson, R. L., Faria, J. C., Ahlquist, P., and Maxwell, D. P. 1993. Genetic diversity in geminiviruses causing bean golden mosaic disease: The nucleotide sequence of the infectious cloned DNA components of a Brazilian isolate of bean golden mosaic geminivirus. Phytopathology 83:709715 .

24. Gilbertson, R. L., Faria, J. C., Hanson, S. F., Morales, F. J., Ahlquist, P., Maxwell, D. P., and Russell, D. R. 1991. Cloning of the complete DNA genomes of four bean-infecting geminiviruses and determining their infectivity by electric discharge particle acceleration. Phytopathology 81: 980-985.

25. Gorbalenya, A. E., and Koonin, E. V. 1989. Viral proteins containing the purine NTP-binding sequence pattern. Nucleic Acids Res. 17:8413-8440.

26. Gorbalenya, A. E., Koonin, E. V., and Wolf, Y. I. 1990. A new superfamily of putative NTP-binding domains encoded by genomes of small DNA and RNA viruses. FEBS Lett. 262:145-148.

27. Idris, A. M., and Brown, J. K. 1998. Sinaloa tomato leaf curl geminivirus: Biological and molecular evidence for a new subgroup III virus. Phytopathology 88:648-657.

28. Jiang, H., Hou, Y.-M., Guzman, P., and Gilbertson, R. L. 1998. Complete nucleotide sequence of tomato leaf crumple geminivirus. (Abstr.) Phytopathology 88 (suppl.):S44.

29. Koonin, E. V., and Ilyina, T. V. 1992. Geminivirus replication proteins are related to prokaryotic plasmid rolling circle DNA replication initiator proteins. J. Gen Virol. 73:2763-2766.

30. Lazarowitz, S. G. 1992. Geminiviruses: Genome structure and gene function. Crit. Rev. Plant Sci. 11:327-349.

31. Lazarowitz, S. G., Wu, L. C., Rogers, S. G., and Elmer, S. J. 1992. Sequence specific interaction with the viral AL1 protein identifies a geminivirus DNA replication origin. Plant Cell 4:799-809.

32. Mayo, M. A., and Pringle, C. R. 1998. Virus taxonomy-1997. J. Gen Virol. 79:649-657.

33. Navot, N., Pichersky, E., Zeidan, M., Zamir, D., and Czosnek, H. 1991. Tomato yellow leaf curl virus: A whitefly-transmitted geminivirus with a single genomic component. Virology 185:151-161.

34. Noueiry, A. O., Lucas, W. J., and Gilbertson, R. L. 1994. Two proteins of a plant DNA virus coordinate nuclear and plasmodesmal transport. Cell 76:925-932.

35. Padidam, M., Beachy, R. N., and Fauquet, C. M. 1995. Classification and identification of geminiviruses using sequence comparisons. J. Gen. Virol. 76:249-263

36. Paplomatas, E. J., Patel, V. P., Hou, Y.-M., Noueiry, A. O., and Gilbertson, R. L. 1994. Molecular characterization of a new sap-transmissible bipartite genome geminivirus infecting tomatoes in Mexico. Phytopathology 84:1215-1224.

37. Rogers, S. G., Bisaro, D. M., Horsch, R. B., Fraley, R. T., Hoffman, N. L., Brand, L., Elmer, S. J., and Lloyd, A. M. 1986. Tomato golden mosaic virus A component DNA replicates autonomously in transgenic plants. Cell 45:593-600.

38. Rybicki, E. P. 1994. A phylogenetic and evolutionary justification for three genera of Geminiviridae. Arch. Virol. 139:49-77.

39. Sanderfoot, A. A., and Lazarowitz, S. G. 1995. Cooperation in viral movement: The geminivirus BL1 movement protein interacts with BR1 and redirects it from the nucleus to the cell periphery. Plant Cell 7:1185-1194.

40. Sharp, L. P., Hou, Y.-M., Garrido-Ramirez, E. R., Guzman, P., and Gilbertson, R. L. 1998. Characterization of a new geminivirus DNA-A component from tomatoes infected with chino del tomate disease. (Abstr.) Phytopathology 88(suppl.):S81.

41. Stanley, J. 1983. Infectivity of cloned geminivirus genome requires sequences from both DNAs. Nature (Lond.) 305:643-645.

42. Stenger, D. C., Duffus, J. E., and Villalon, B. 1990. Biological and genomic properties of a geminivirus isolated from pepper. Phytopathology 80:704-709.

43. Sunter, G., Gardiner, W. E., Rushing, A. E., Rogers, S. G., and Bisaro, D. M. 1987. Independent encapsidation of tomato golden mosaic virus A component DNA in transgenic plants. Plant Mol. Biol. 8:477-484.

44. Swofford, D. L. 1991. PAUP User's Manual. Illinois Natural History Survey, Champaign

45. Torres-Pacheco, I., Garzon-Tiznado, J. A., Brown, J. K., Becerra-Flora, A., and Rivera-Bustamante, R. 1996. Detection and distribution of geminiviruses in Mexico and southern United States. Phytopathology 86:11861192.

46. Wyatt, S. D., and Brown, J. K. 1996. Detection of subgroup III geminivirus isolates in leaf extracts by degenerate primers and polymerase chain reaction. Phytopathology 86:1288-1293. 